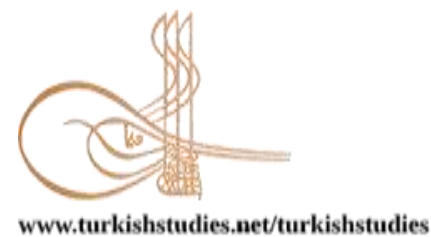

Turkish Studies

\title{
Romanlarda Çocuk Yoksulluğu: Kocaeli Tavşantepe Mahallesi Örneği ${ }^{*}$
}

\author{
Child Poverty In Romans: An Example Of Tavşantepe Neighborhood, Kocaeli
}

\author{
Elvan Okutan** - Rukiye Turgut ${ }^{* * *}$
}

\begin{abstract}
Poverty is often caused by problems with access to resources that must be found for the survival of humanity and societies. Because of child poverty and the poverty of the family lived together, the child was not the only one who lived with him. inability to access or access the necessary facilities for physical, spiritual, and social development and progression. A species studied in the ethnic characteristics of poverty species is Roman poverty. The community, known by the novel name, has a history of its beginnings based on India. Today, they are called Roman as well as gypsy. The Roma community, which was excluded by society, isolated from a number of social environments and otherized, has taken the form of a community that is pushed into poverty, which can also take an active role in working life. As a result of the cultural characteristics possessed by society, the child of the novel family who was left poor by being excluded by society lives differently in poverty. This study was carried out to examine the poor state of the Roma child and the consequences of its inability to access their needs as a result. The individual and social reasons of the poverty situation present in the research field were interviewed and examined. In the review, interviews were conducted with the elders of the household and the interviews were analyzed by nvivo12 qualitative data method. As a result of the research, roma found that child poverty depends on social causes together for individual reasons. It was concluded that the individual cause of poverty was due to the ethnic and cultural characteristics that were possessed, and that the social cause was unemployed as a result of changes in the business markets as a result of capitalism and globalization.
\end{abstract}

Structured Abstract: Introduction: Poverty is a social phenomenon that has been struggling for years as a problem of societies. Due to certain ethnic and cultural characteristics, the poverty of the Roma community is a special type of poverty. Roma child poverty has been studied as a form of child poverty, which includes a special examination of family poverty, which includes the deprivation of children in this group, and that has the disadvantaged group character.

\footnotetext{
* Bu çalışma, Dr. Öğretim Üyesi Elvan Okutan danışmanlığında, Rukiye Turgut tarafından hazırlanan "Romanlarda Çocuk Yoksulluğu: Kocaeli Tavşantepe Mahallesi Örneği” konulu yüksek lisans tezinden (2019) birebir yararlanılarak oluşturulmuştur.

** Dr. Öğretim Üyesi, Sakarya Üniversitesi, Siyasal Bilgiler Fakütesi, Çalışma Ekonomisi ve Endüstri İlişkileri

Asst. Prof., Sakarya Universtiy

ORCID 0000-0002-9082-8850

elvany@sakarya.edu.tr

*** YL Öğrencisi, Sakarya Üniversitesi, Sosyal Bilimler Enstitüsü, Çalışma Ekonomisi ve Sosyal Siyaset

Master Stident, Sakarya Universtiy

ORCID 0000-0001-6454-6035

r.turgut@yandex.com

Cite as/ Atıf: Okutan, E., Turgut, R. (2020). Romanlarda çocuk yoksulluğu: Kocaeli Tavşantepe Mahallesi örneği. Turkish Studies, 15(5), 2523-2543. https://dx.doi.org/10.7827/TurkishStudies.43578

Received/Geliş: 14 May/Mayıs 2020

Accepted/Kabul: 25 August/Ağustos 2020

Checked by plagiarism software

Copyright $($ ) MDE, Turkey

Published/Yayın: 31 August/Ağustos 2020

CC BY-NC 4.0
} 


\section{Purpose}

Child poverty, which is one of the types of the concept of poverty, started to be noticed at the end. This takes into account the child's poverty. Poverty, which is raised within the Roma community, an ethnic race, and where they are children, lives in a different way. The society is excluded by community members due to the certain ethnic characteristics it has. This sample needs to be investigated and necessary due to poverty in Roma biological life. Based on this idea, the investigations aimed to investigate, examine and evaluate the causes and examination of the deprivation and vital problems caused by the poverty experienced by the Romans in the research area, which is the Roma neighborhood.

\section{Method}

The research has qualitative research feature and was carried out with a field study on 15 people. Qualitative research is carried out regularly by examining different social environments and the groups or individuals that make up these environments (Berg and Lune Trans. Ar1, 2019: 20) Qualitative researchers; people look at how they interpret their lives, what they add to this world, what they have used, and the age they have experienced, and what they attribute to the events they have experienced (Merriam Trans. Turan, $2015 ; 14)$. An ethnographic research was carried out. Qualitative research on ethnography; is to conduct field research by spending time among people with a certain culture. He benefited from the semi-formal interview method in the field study. Open-ended questions were asked. The formal interview is the interviews consisting of the necessary questions beforehand. The semi-formal interview method has a rough outline form (Erbaş, 2018; 25).

In categorizing the interview questions; Ayşe Buğra's' Capitalism, Poverty and Social Policy in Turkey, " noted the paragraph in the book has benefited from individual causes of poverty (Buğra, 2018; 11). The voice recordings and notes taken during the interviews with individuals included in the research group were converted into text in the computer environment and made concrete. The data obtained as a result of the field study was analyzed with a descriptive analysis approach. Content analysis was performed by using NVIVO 12 qualitative data analysis program, which is one of the qualitative data analysis tools. Firstly, the interviews were categorized and coded. Afterwards, similarities and differences of these codings were brought together and comparisons were made and interpreted.

\section{Results}

The phenomenon of child poverty is not a phenomenon that occurs on its own. It will bring the necessary rights and freedoms, needs, vital needs and childhood for your children who grow up in poverty. A child growing up in this way is having a healthy adulthood. Exceptionally self-improving, it absorbs the impossibilities experienced in childhood, and this lesson of his family is available in adults with a remarkable good life.

The Roma child has a different poor structure than other children. The ethnic and cultural characteristics of poverty that are the individual causes of poverty cause their poverty to be perceived as a property of them. Due to these features, although they are excluded in the environments they enter, nonRoma people are not allowed to enter the environments where they are located with movement and attitudes, and even with direct words. These features cause negative effects in education life.

Due to the lack of education, which is one of the individual causes of Roma poverty, the environments in which they are employed are restricted and directed towards informal jobs. It has been understood that poverty has occurred because the family members working in such jobs cannot use the incoming money well and do not know their account. On the other hand, the changes in the labor markets caused the professions of the Roma sector to disappear.

Changes in labor markets, which are the social causes of poverty, It has been determined that Roma society is one of the causes of poverty. Despite all these impossibilities and difficulties, Roma children in Tavsantepe District try to continue their education, but there are problems because they are Roma. Due to the fact that the family of Tavsantepeli Roma children is in seasonal migration to the workers, they start school late after the school opens from the cities they visited. The Roma child, who started school late, lags behind the lessons and has difficulty in adapting to the school environment because he cannot get help from the family about the lesson and cannot have the necessary resources for his lessons and homework. In addition to 
this difficulty, he is excluded because he is a Roma at school. The excluded child cools and goes away from the school environment and education.

Due to the poor situation that the family is in and the loss of time in education, the child chooses to contribute to the livelihood of his family instead of going to school or spends free time. These people, who are not accepted to the society and isolated from the society, are impress while they are still a child. This situation transfers itself from generation to generation. No matter how many children want to read, this situation can not be done.

Regarding the reading of the girls, the reading of the girl after reaching a certain age is not supported and taken from the school by showing the reasons for the abduction in the neighborhood. A vicious circle that continues in this way occurs and passes from generation to generation. While the situation is in this state today, it is a point that makes people think that it will not be much different tomorrow. It seems that the Roma community will continue to lead a unique lifestyle in every geography and the society will continue to look at them with a bad eye. The prejudice of society is a major obstacle in the development of this Roma individual. Initially, the problems they face in education arise from the current biased behaviors of the society.

Keywords: Social Policyt, Romans Poverty, Child Poverty, Poverty, Gypsy

Öz: Yoksulluk, genel olarak insanlığın ve toplumların hayatlarının devamı için bulunması gereken kaynaklara erişimde karşılaşılan sorunlar ile meydana gelir. Çocuk yoksulluğu, beraber yaşanılan ailenin yoksulluğu sebebiyle çocuğun; fiziksel, ruhsal ve sosyal gelişimi ve ilerlemesi için gerekli imkanlara erişilememesi veya kısıtlı bir şekilde erişilmesi durumudur. Yoksulluk türlerinin etnik özellikler dalında incelenen bir tür de Roman yoksulluğudur. Roman adı ile bilinen topluluk, başlangıcının Hindistan'a dayandığı bir geçmişe sahiptir. Günümüzde Roman ismi ile adlandırılmalarının yanında Çingene ismi ile de çağırılmaktadırlar. Toplum tarafından dışlanarak, bir takım sosyal ortamlardan izole edilen ve ötekileştirilmeleri sonucunda, çalışma hayatında da aktif rol alamayan Roman topluluğu, yoksulluğa itilen bir topluluk şeklini almıştır. Sahip olunan kültürel özelliklerin sonucunda toplum tarafindan dışlanma ile yoksul bırakılan roman ailenin çocuğu yoksulluğu daha farklı yaşamaktadır. Bu çalışma, Roman çocuğun içinde bulunduğu yoksul durumu ve bunun neticesinde ihtiyaçlarına erişememe durumunun nedenleri ve sonuçlarını incelemek amacıyla gerçekleştirilmiştir. Araştırma sahasında mevcut bulunan yoksulluk durumunun bireysel ve toplumsal nedenleri mülakat yapılarak incelenmiştir. İncelemede, hanede bulunan aile büyükleri ile mülakat yapılmış ve mülakatlar NVIVO12 nitel veri yöntemi ile analiz edilmiştir. Araştırma sonucunda Roman çocuk yoksulluğunun bireysel nedenlerle birlikte toplumsal nedenlere de bağlı olduğu anlaşılmıştır. Yoksulluğun bireysel nedeninin, sahip olunan etnik ve kültürel özelliklerden kaynaklandığı, toplumsal nedeninin ise kapitalizm ve küreselleşme sonucunda iş piyasalarındaki değişiklikler neticesinde işsiz kalındığı sonucuna varılmıştır.

Anahtar Kelimeler: Sosyal Politika, Roman Yoksulluğu, Çocuk Yoksulluğu, Yoksulluk, Çingene

\section{Giriş}

Yoksulluk kavramı bulunulan ortama ve şartlara göre farklı şekillerde tanımlanmaktadır. Yoksulluk geniş bir tanıma sahip olsa da özel yoksulluk türleri ile kısıtlandırılarak açıklanabilmektedir. Bu özel yoksulluk türlerinden olan çocuk yoksulluğu ailenin içinde bulunduğu yoksulluktan ötürü oluşan bir türdür ve genel olarak sebepleri de ailenin yoksulluk sebeplerine bağlı olmaktadır. Roman topluluğunun yoksulluğu ise etnik özelliklerden dolayı meydana gelen bir diğer yoksulluk türüdür. Ailenin sahip olduğu küaltürel özelliklerin diğer toplumlarca kabul görmeyişi ve dışlanması ile Roman birey iş piyasalarında kendini gösterememekte ve yoksulluğa itilmektedir. Burada yine dezavantajlı konumda yer alan çocuklar bu yoksulluğu en derinde yaşamakta bunun neticesinde Roman çocuk yoksulluğu ortaya çıkmaktadır.

$\mathrm{Bu}$ düşünceden hareketle, çalışmada Roman çocuğun içinde bulunduğu yoksul durumun incelenmesi, sebepleri ve sonuçlarının araştırılması amaçlanmıştır. 
Araştırmada, hane bireyleri ile mülakatlar gerçekleştirilmiştir. Yapılan mülakatlar NVIVO12 nitel veri analizi yöntemi ile incelenmiş ve yorumlanmıştır. Araştırmanın evreni, Kocaeli'de Roman topluluğunun yaşadığı mahalle olan Tavşantepe mahallesinde bulunan ve okul çağında çocuklara sahip olan hane bireylerinden oluşmaktadır.

Bu kapsamda çalışma 3 bölümden oluşturulmuştur. Öncelikle birinci ve ikinci bölümde çocuk yoksulluğu ve Roman topluluğu adına literatür taraması yer alırken, son bölümde ise araştırma bulgu ve analizlerine yer verilmiştir.

\section{Kavramsal Çerçeve}

\subsection{Yoksulluk ve Çocuk Yoksulluğu}

Yoksulluk Dünya Bankası tanımına göre; belirli bir gelirin altında kalan ve temel ihtiyaçlarını karşılayacak gelire sahip olmayanlardır (www.worldbank.org). Yoksulluk genel olarak, toplumun veya toplumda bulunan belirli bir kesimin yaşamını idame ettirebilmesi için gerekli olan gida, giyim ve yaşanacak bir ev gibi en basit zorunlu ihtiyaç malzemelerinin mevcudiyeti durumudur (Uzun, 2003: 156). Diğer yandan dar anlamda yoksulluk ise bireyin açlıktan ölme ve barınacak yeri olamaması durumu olarak belirtilmektedir (Kiren Gürler, 2011: 4). Bunun yanında ABD, Almanya ve İngiltere'de gerçekleştirilen araştırmalarda yoksulluğun geçici bir süreç olarak kabul edildiği sonucuna varılmıştır. Bu görüşteki bireyler, yoksulluk sınırının altında veya haricinde kalan kısa süreli bir yoksulluk dönemi geçirmenin ardından tekrar eskiye yaşamsal faaliyetlerine dönmektedir (Baulch ve McCulloch, 1998: 3).

Birleşmiş Milletler tanımına göre çocuk kavramı; erken yaşta ergin olma durumu dışında on sekiz yaşın altında kalan kesim olarak belirlenmiştir (BM Çocuk Haklarına Dair Sözleşme, 1989: madde 1). Çocuk kavramı genellikle yaş ile kısıtlansa bile bu kısıt; ülkeye, cinsiyete, kır-kent arası farkına ve uluslararası belgelere göre değişebilmektedir (Tokol ve Alper, 2017: 404).

Çocukluk kavramı algısında zamanla meydan gelen gelişmenin, çocuk yoksulluğu kavramının oluşmasının yanında çocuk yoksulluğunun özellikle incelenmesinde rol oynadığ1 düşünülmektedir (Öztürk, 2008: 18). Çocukların içinde bulunduğu aile ve ortamdan dolayı ortaya çıkan çocuk yoksulluğu kavramı UNICEF' in 2005 senesinde yayımladığ "Dünya Çocuklarının Durumu" adlı raporda (Kahraman ve Sallan-Gül, 2015: 343): "Çocuğun; yaşama, büyüme ve gelişimi yönünden zaruri maddi, manevi ve duygusal kaynaklardan yoksun olması durumu" olarak tanımlanmıştır (UNICEF, 2005:18). Yoksul aileler çocuklarının; zihinsel, bedensel ve duygusal açıdan gereksinimlerini karşılayamamakla birlikte, çocukların istismara, şiddete ve ayrımcılığa uğramasına da engel olamamaktadır (Durgun. 2011: 145). Çocuk yoksulluğu, gelecekteki üretim seviyesi ve yaşam standardı açısından uzun vadede etki alanına sahiptir. Gelişmekte olan ülkelerdeki çocukluk çağı yoksulluğu, çoğunlukla yetersiz gıda tüketimine ve kısa boyluluğa yol açmaktadır (Barrientos and Dejong, 2006:538).

Çocuk yoksulluğunun nedenlerine bakılacak olursa bu nedenler bireysel nedenler ve toplumsal nedenler olmak üzere iki başlık altında toplanmıştır.

\section{Çocuk Yoksulluğunun Bireysel Nedenleri}

Aşağıda belirtilen nedenler ailenin yoksulluğuna bağlı olması sebebi ile çocuk yoksulluğunun da nedenleridir.

Aile Hayatının Düzensizliği: Geniş ve çekirdek aile türlerinin yanı sıra ebeveyn eksikliğine göre aile türleri de bulunmaktadır. Bu aileler baba veya annenin vefatı ile veya boşanma sonucu ile oluşan ailelerdir. Günümüzde çocuklarda oluşan pek çok sorun ailenin parçalanması ile ilgilidir. Böyle ailelerde maddi yetersizlikler baş göstermektedir ve bu da çocuğun hayatını olumsuz yönde etkilemektedir (Yusufoğlu ve Kızmaz, 2012: 30). 
Çok Çocuk Sahibi Olmak: Gelişmiş ve az gelişmiş ülkelerde ailelerdeki çocuk sayısının yoksullukla yakın ilişkili olduğu gözlemlenmiştir (Şenses, 2014:159). Gelişmekte olan ülkelerde gerçekleştirilen araştırmalarda yoksul çocukların ortak özelliğinin kalabalık ailede yaşamalarıdır. Doğurganlık oranının yüksek olduğu bu aileler, çocuğun kısa zamanda iş gücüne dönüşmesi durumundan ötürü bu tutumu sergilemektedir. Çocuksuz olan veya çocuk sayısı 1- 2'yi geçmeyen çekirdek ailelerde ise yoksulluk oranı düşük seviyelerdedir (Durgun, 2011: 149)

Tembellik: Tembellik kimi düşünürler tarafindan olumlu bir şekilde karşılanan ve gerekli olduğu düşünülen bir durumdur. Lafague "Tembellik Hakkı" (1883) isimli eserinde çalışmaya karş1 tutum sergilemekte ve çalışma saatlerinin günde en çok 3 saat olmasını savunmaktadır. Arda kalan zamanda ise insanların yaratıcı yönlerini ortaya çıkarmaları için serbest bırakılması gerektiğini savunmaktadır (Aytaç, 2005: 4-5). Diğer yandan günümüzde böyle bir durum mümkün olmadığından, tembellik yapan, çalışmayan insanlara kötü gözle bakılmaktadır ve bu süreçte alınan sosyal yardımların bu insanları daha çok tembelliğe sevk ettiği düşünülmektedir (Teber, 2017: 10)

Ĕgitim Durumu: Hanede bulunun hane reisinin eğitim seviyesinin düşük olması yoksulluk araştırmalarında önemli bir yere sahip olduğu ve bu eğitim seviyesinin yüksek olması ile aile için yoksulluk seviyesinin azaldığı yapılan çalışmalarda görülmektedir (Şenses, 2014:160). Teknolojinin gelişimi ile istihdam yapısının değişmesi sebebiyle kabiliyetli ve bilgiye sahip çalışana olan ihtiyaç artmaktadır (Özdemir, 2014: 21)

Etnisite: Etnisite, bireyin yaşanılan topluma karşı kendini farklı hissetmesi veya toplumun bireyi farklı hissetmesi durumudur (Nişancı ve Işık, 2015:197). Etnisite, bazı etnik grupların yerli halk tarafından ekonomik alanlardan dışlanmaları ve düşük seviyedeki işlerde istihdam edilmelerine sebep olmaktadır (Koptekin, 2017: 85).

Göç: Yoksulluk olgusunun temel etmenlerinin başında farklı nedenlerle gerçekleşen göç hareketi gelmektedir (Şenses, 2014:161).

Hesabını Bilememek: Geç modern hayatın en önemli kültürü olan tüketim kültürü, kimliksel farklılık ve kimliğin belirlenmesi konusunda bireye özel bir nitelik yüklemektedir. Bu tüketim kültürü bireyi sürekli yeni tüketim araçlarına yönlendirmektedir. Ürünü veya hizmeti bekletmeden bitirmeyi mesaj olarak vermektedir. Bu sebeple zaruri ihtiyaçların dışında farklı ihtiyaçlara yönelinmesi durumunda mevcut bulunan gelirin gideri karşılayamama durumu ortaya çıkmaktadır (Karakaş, 2006:3-6)

\section{Çocuk Yoksulluğunun Toplumsal Nedenleri}

Kapitalizmin Yoksulluğa Etkisi: Kapitalizm, kökeninde çalışmayı bulunduran bir toplum düzenidir (Buğra, 2018: 10). Kapitalizmin ardından gelen küreselleşme olgusu kapitalizm düzeninin dünyaya yayılmasına sebep olmuştur. Dünyanın giderek zengin bir hale gelmesi ve aynı zamanda yoksulluğun artış göstermesi, kaynakların ve hizmetlerin kapitalizm sebebi ile adaletsiz bir şekilde dağıtılmasının bir sonucudur (Yusufoğlu ve Kızmaz, 2012: 27).

Küreselleşmenin Yoksulluğa Etkisi: Küreselleşme genel olarak, dünyanın küçük bir köy olması hali olarak açıklanmaktadır (Çeken vd.,2008:88). 1980'li yıllardan sonra dünyayı etkisi altına alan küreselleşme, yoksulluğun etkilediği alanı genişletmiştir (Sipahi, 2006:173). Bugün sermayenin küreselleşmesi ile işgücünün küreselleşmesi gerçekleşmiştir ve bu da ucuz iş gücüne yönelimi arttırmıştır (Uğurlu, 2013: 74).

Nüfus Artışı: Hızlı nüfus artışı özellikle az gelişmiş ülkelerde yoksulluğun önemli nedenlerinden biri olarak görülmektedir (Şenses, 2014: 154-156). Nüfus artış1 iki şekilde meydana gelmektedir. Bunlar; doğurganlık oranının atması ve ölüm oranının düşmesidir (Başel, 2007: 524$525)$. 
İş Piyasaları: İş piyasalarında meydana gelen değişimler, işverenler tarafından artık makime ve bilgisayar sistemlerinin ikame edildiği özelliklere sahip çalışanların işten çıkarılmasına neden olmaktadır (Özdemir, 2014: 21).

\subsection{Roman Kimliği}

Romanlar, kullandıkları dilden ötürü filolojik araştırmaların sonucunda 7. ve 10. Yüzy1llar arasında Hindistan sınırları civarında ortaya çıktığı ve anayurtları Hindistan olduğu bilim insanları tarafından ortaya çıkarılan etnik bir topluluktur (Altınöz, 2013: 28, Kenrick, 2006: 18). Roman kimdir? Sorusu tam olarak cevaplanamamaktadır ve Roman olanla Roman olmayan arasındaki farklar ve bunun kalıcılığı konusundaki tartışmalar geçmişten bu yana devam etmektedir (Mayall, 2004). Genel olarak "çingene" kelimesi ile çağırılan Roman topluluğu, kendilerine ait olan dikkat çekici tavırları ve hareketleri ile kent ve kır kesimi içerisinde yaşam tarzları, iktisadi faaliyetleri, eğitim alanındaki konumları ve çalışma hayatına dahil olma süreçleri ile sosyal politikaların yakın ilgi duyduğu dezavantajlı gruplar arasında bulunmaktadır (Çetin, 2017).

Romanlar konusunda yapılan araştırmalara bakıldığında, dünyanın birçok yerinde farklı isimlerle anıldıkları ve kendilerine has kültürleri ve yaşam tarzına sahip bir topluluk oldukları kabul edilmiştir (Özdemir, 2017: 152). Avrupa'da oradaki halk tarafından "Bohemyalılar, Kıptiler, Çiganlar ve Zigeuner" isimleri ile çağrılmışlardır (Asseo, 2004: 13). Farklı yaşam tarzları ile gittikleri ülkelerde ya oradaki kültür içerisinde kaybolmuşlar ya da girdikleri toplum ve ortamlara farklılık katmışlardır (Uçum, 2008: 25). Genel olarak sayısal olarak büyük bir azınlık grubunu oluşturmuşlardır ve Avrupa'da yaşayan "vatansızlar", "topraksızlar" olarak görülen topluluktur (Alp, 2015:3).

Roman topluluğunun, Anadolu'ya ne zaman geldikleri net olarak bilinmemektedir (Altınöz, 2013:31). Türkiye'de, göç eden Roman topluluğunun kolları olarak; Rom, Dom ve Lom gibi farklı gruplar yer almaktadır. Tarih boyunca Çingene ismi ile anılan Roman topluluğu bu isme atfedilen olumsuz anlamlar, dışlanma ve toplumdan izole edilme gibi ötekileştirme durumları sebebi ile bu kelimenin getirdiği olumsuz düşüncelerden uzaklaşmak istemektedir (Uğurlu ve Duru, 2010:4).

Öte yandan Roman topluluğu geçmişten süregelen bazı önyargılar ile sosyal dışlanma ve ötekileştirme başta olmak üzere, yoksulluk, işsizlik, temel hak ve hizmetlere erişimde sorunlarla karşılaşılan bir topluluktur (Çetin, 2017: 86).

\subsection{Roman Çocuk Yoksulluğu}

Roman topluluğunun yoksulluğu; piyasa şartlarına göre eğitim ve yetenek eksikliğinden ötürü gerçekleşmektedir. Bu yoksulluk nesilden nesile aktarılmakta ve bu durum kısır döngü halini almaktadır (Özateşler, 2013: 16). Sahip olunan belli etnik özelliklerden ötürü etiketlenme ve yoksulluğun yarattığı olumsuzluklar en çok Roman çocuğu etkilemektedir. Roman topluluğunun günlük hayatta karşılaştığı ekonomik, kültürel ve eğitim sorunları Roman çocuğun hayatını derinden etkilemekte ve bu etki kısır döngü halinde diğer nesillere aktarılmaktadır (Alp, 2015: 11). Roman çocukların karşılaştı̆̆ sorunlar şu şekildedir:

Ë̆itim: Roman çocukların okul terk oranı, devamsızlık ve bir üst sınıfa geçmiş olsa dahi okuma yazmayı öğrenememiş olması gibi durumlarla çok fazla karşılaşılmaktadır. Roman aileler yoksulluk sebebi ile çocukların eğitimini uzun süreli ve sonu belli olmayan bir yatırım olarak görmektedir. Bu sebeple çoğu Roman çocuk maddi yetersizliklerden ötürü eğitim hayatını yarım bırakmakta veya devam etmesi halinde dışlanma faktörü ile karşılaşması durumunda eğitime devam edememektedir (Aile ve Sos. Pol. Bakanlığı, 2016).

Barınma: Roman topluluğu, uzun yıllardan beri kendi kültürlerine göre barınma şekillerine sahiptir. Yaşanılan haneleri genellikle kendileri derme çatma şekilde yaptıklarından (Aile ve Sos. 
Pol. Bakanlığı, 2016) sağlıklı bir yaşama ortamı sağlanamamaktadır. Yaşanılan haneler dar ve kalabalık aile bireylerinden oluşmaktadır (Koptekin, 2017: 127).

Sağlık: Să̆lık hizmetlerine ulaşım konusunda diğer faktörler kadar sorun yaşanmamaktadır. Sağlık sigortasına sahip olmayan bireylere devlet tarafindan Genel Sağlik Sigortası'ndan yararlanabilme büyük fayda sağlamıştır. Birinci derece sağlık hizmeti olan sağlık ocaklarından memnun oldukları gözlemlenmiştir (Akkan vd., 2011:73-74). Fakat son dönemde, insan sağlığının korunması ve tedaviler karşıllı̆ında para ödenmesi durumu artmıştır ve bu da Roman topluluğunu zor duruma sokmuştur (Aşkın, 2012: 22).

Erişim: Romanlara karşı diğer insanların gösterdiği tutumlar, onların içinde bulundukları yoksulluk ve sosyal dışlanma gibi sorunları daha şiddetli yaşamalarına neden olmaktadır (Fırat ve İlhan, 2019: 265-266). Sahip olunan etnik ve kültürel özellikler sinıfsal farklılıkları berberinde getirmektedir. Sinıfsal farklılıklar ise toplum içerisinde tabakalaşmaya sebep olmakta ve tabakalaşan toplumda eğitim, barınma ve sağlık alanlarında erişimsel sorunlar meydana gelmektedir. Kültürel farklılıklar, sınıf ayrımına yol açmakta ve oluşan eşitsizliklere sahip olunan haklara erişim kısıtlanmaktadır (Genç vd., 2015: 85).

Madde Bă̆ımlılı̆̆ı: Aile bireylerinin çocukları ile ilgilenmemeleri, yaşanılan ekonomik sorunlar, şehir hayatına uyumsuzluk ve eğitimsizlik çocukları evin dışındaki ortama itmektedir (Başkurt, 2003: 75). Roman mahallelerinde ve Roman çocukların çevrelerinde uyuşturucu madde satışları yaygın olduğu için bu çocuklar bu konuda bilgiye sahip olarak büyümektedir. $\mathrm{Bu}$ çocukların ihmali söz konusu olduğunda ise uyuşturucu ve keyif verici maddelere yönelimleri artacak ve birer madde bağımlıları halline gelmeleri kaçınılmaz bir hal alacaktır (Koptekin, 2017: 102).

\section{Romanlar 'da Çocuk Yoksulluğuna Dair Bir Araştırma}

\subsection{Araştırmanın Yöntemi}

\subsubsection{Araştırmanın Amacı}

Yoksulluğun özel türlerinden biri olan çocuk yoksulluğu son dönemlerde çocuk kavramının değer kazanmasıyla incelenmesi gereken bir dal olarak kabul edilmeye başlanmıştır. Farlı kültür ve etnik özelliklerinden ötürü büyük bir azınlık konumunda olan Roman topluluğunda yetişen çocuk yoksulluğu daha derin bir şekilde yaşamaktadır. Bu düşünceden hareketle Roman çocuk yoksulluğunun nedenleri ve sonuçlarını incelemek amaçlanmıştır.

\subsubsection{Araştırmanın Soruları}

Çalışma şu sorular eşliğinde gerçekleştirilmiştir; araştırmanın ana soruları şu şekildedir:

- $\quad$ Romanlarda çocuk yoksulluğu bireysen nedenlerden mi kaynaklanmaktadır?

- Romanlarda çocuk yoksulluğu toplumsal nedenlerden mi kaynaklanmaktadır?

Araştırmanın alt soruları aşağıdaki şekilde sıralanmıştır:

- Roman kesiminde var olan yoksulluk ve beraberinde gelen çocuk yoksulluğu bireysel nedenlerden mi kaynaklanmaktadır?

- Roman bireyin tembel olması, istihdama katılmaması sonucu mu yoksulluk meydana gelmektedir?

- Aile planlaması yapılmadan çocuk sayısının fazla olması ve gelirin az olması yoksulluğa neden olmakta midır?

- Başta ekonomik nedenler olmak üzere çeşitli nedenlerden ötürü yaşanan göçler sonucunda mı yoksulluk meydana gelmektedir?

- Hesabını bilmeden harcama yapmak, yarını düşünmeden birikim yapmamak mı ekonomik sıkıntılar doğurmaktadır? 
- Roman toplumunun sahip olduğu etnik ve kültürel özelliklerden ötürü istihdam edilmesinde yaşanan sıkıntıların sonucunda $\mathrm{m} ı$ yoksulluk meydana gelmektedir?

- Aile hayatının düzensiz olması mı yoksulluğa sebep olmaktadır?

- Roman bireyin eğitimsizliğinden ötürü istihdam sürecine katılmakta zorluk çekmektedir, bunun sonucunda mı yoksulluk meydana gelir?

- Roman kesiminde var olan yoksulluk ve bunun yanında yer alan çocuk yoksulluğu toplumsal nedenlerden mi kaynaklanmaktadır?

- Kapitalizm ve küreselleşme sebebiyle iş piyasalarında meydana gelen değişimler mi yoksulluğa neden olmaktadır?

- Gelişen teknoloji sebebiyle iş piyasalarında meydana gelen değişimler mi yoksulluğa yol açmaktadır?

- Nüfus artışı sonucunda mı yoksulluk meydana gelmektedir?

\subsubsection{Araştırmanın Sınırılılıkları}

Bu çalışma, Kocaeli ili İzmit ilçesi Tavşantepe Mahallesinde bulunan hane sahipleri ile gerçekleştirilen 15 kişilik yarı biçimsel mülakat yöntemi ile yapılmıştır. Görüşmelerde çocuklarla görüşülmemiş, sadece hane büyükleri ile görüşmeler sağlanmıştır. Araştırma 9 aylık bir mülakat sürecinden oluşmaktadır. Saha araştırmasının uzun zaman sürmüş olmasının nedeni; olumsuz hava koşulları sebebi ile hane sahiplerin evden dışarı çıkmayışları, bireylerin mülakat görüşmelerine olumsuz bakmalarından ötürü mülakata katılmamaları neden olmuştur.

\subsubsection{Araştırmanın Evren ve Örneklemi}

Araştırmanın evreni Kocaeli ili, İzmit ilçesi, Tavşantepe mahallesinde bulunulan Roman topluluğunu içermektedir. Örneklem seçiminde önceden belirlenmiş olan kriterlere uygunluğun araştırılmasını sağlayan ölçüt örneklem yönteminden faydalanılmıştır. Bundan hareketle örneklem, Tavşantepe mahallesi evreni içinde bulunan Roman ailelerden okul çağında çocuklara sahip olanları seçilerek örneklem oluşturulmuştur.

\section{Araştırmanın Bulguları}

\subsection{Katılımcıların Demografik Özellikleri}

Araştırma sahasında yapılan 15 kişilik görüşmelerde görüşülen hane sahiplerinin demografik verileri şu şekildedir:

Tablo 1: Mülakatta Görüşülen Hanelerin Demografik Bilgileri

\begin{tabular}{|c|c|c|c|c|c|c|c|}
\hline \multirow[t]{2}{*}{ Meslek } & \multirow[t]{2}{*}{ Kod } & \multirow[t]{2}{*}{ Cinsiyet } & \multirow[t]{2}{*}{ Yaş } & \multicolumn{2}{|c|}{$\begin{array}{c}\text { Okul Çağındaki } \\
\text { Çocuk Sayısı (7-18 } \\
\text { Yaş) }\end{array}$} & \multicolumn{2}{|c|}{$\begin{array}{c}\text { Okula Giden- } \\
\text { Devam Eden Çocuk } \\
\text { Sayısı } \\
\text { (7-18 Yaş) }\end{array}$} \\
\hline & & & & Klz & Erkek & Kiz & Erkek \\
\hline \multirow{4}{*}{ Servis } & (D.T.) & $\begin{array}{l}\text { Kadın } \\
\text { (Anne) }\end{array}$ & 32 & -- & 1 & -- & 1 \\
\hline & (Y.G.) & $\begin{array}{l}\text { Kadın } \\
\text { (Anne) }\end{array}$ & 29 & 2 & -- & 2 & -- \\
\hline & (Ç.B.) & $\begin{array}{c}\text { Kadın } \\
\text { (Babaanne) }\end{array}$ & 53 & 1 & -- & 1 & -- \\
\hline & (Ş.B.) & $\begin{array}{l}\text { Erkek } \\
\text { (Baba) }\end{array}$ & 37 & -- & -- & -- & 1 \\
\hline \multirow{3}{*}{ Hurdacılık } & (I) & $\begin{array}{c}\text { Kadın } \\
\text { (Babaanne) }\end{array}$ & 36 & & 1 & -- & 1 \\
\hline & (R.K.) & $\begin{array}{l}\text { Kadın } \\
\text { (Anne) }\end{array}$ & 24 & 1 & -- & 1 & -- \\
\hline & (E.P.) & Kadın & 24 & -- & 1 & -- & 1 \\
\hline
\end{tabular}

Turkish Studies, 15(5) 


\begin{tabular}{|c|c|c|c|c|c|c|c|}
\hline \multirow{5}{*}{$\begin{array}{c}\text { Emekli veya Engelli } \\
\text { Maaşı ve } \\
\text { Yardımlarla İle } \\
\text { Geçinen }\end{array}$} & & (Anne) & & & & & \\
\hline & (Y.T.) & $\begin{array}{l}\text { Erkek } \\
\text { (Baba) }\end{array}$ & 28 & ---- & 2 & -- & 2 \\
\hline & (H.Y.) & $\begin{array}{c}\text { Kadın } \\
\text { (Babaanne) }\end{array}$ & 58 & 1 & 1 & -- & 1 \\
\hline & (N.İ) & $\begin{array}{l}\text { Kadın } \\
\text { (Anne) }\end{array}$ & 42 & 1 & -- & -- & -- \\
\hline & (B.A.) & $\begin{array}{l}\text { Erkek } \\
\text { (Dede) }\end{array}$ & 59 & 1 & -- & 1 & -- \\
\hline \multirow[t]{3}{*}{$\begin{array}{c}\text { Asgari Ücret ile } \\
\text { Geçinen }\end{array}$} & (Ç.A) & $\begin{array}{l}\text { Erkek } \\
\text { (Baba) }\end{array}$ & 41 & -- & 1 & -- & 1 \\
\hline & (E.T.) & $\begin{array}{l}\text { Kadın } \\
\text { (Anne) }\end{array}$ & 32 & 1 & 1 & -- & -- \\
\hline & (O) & $\begin{array}{l}\text { Kadın } \\
\text { (Anne) }\end{array}$ & 47 & 1 & 1 & -- & 1 \\
\hline $\begin{array}{c}\text { İşsiz } \\
\text { (Bohça, Çorap } \\
\text { Satarak Geçinen) }\end{array}$ & (G.Y.) & $\begin{array}{l}\text { Kadın } \\
\text { (Anne) }\end{array}$ & 27 & 1 & -- & -- & -- \\
\hline
\end{tabular}

Gerçekleştirilen mülakatlarda bireyler ad ve soyadı baş harfleri ile kodlanmış ve hanenin geçim türüne göre kategorize edilmiştir (Tablo 1).

\subsection{Roman Çocuk Yoksulluğunun Bireysel Nedenleri}

\subsubsection{Tembellik}

Birey, yaşamının devamı adına çalışma hayatında aktif olarak rol almalıdır. Çalışma kabiliyet ve imkanına sahip olduğu halde çalışmayan bireyi toplum tembel tembel olarak görmektedir. Tembellik teması altında, mevcut bulunan Roman çocuk yoksulluğunun kökeninde bulunan ailenin yoksul olma sebebinin, hane bireylerinin tembel olmasından ötürü mü kaynaklandığ 1 incelenmiştir. Yoksulluğun bireysel nedenlerinden olan tembellik teması altında evde işsiz bir yetişkin bireyin olup olmadığı, haneye giren gelir miktarı ve herhangi bir ayni veya nakdî yardım alınıp alınmadığını öğrenmek amacı ile sorular yöneltilmiştir ve bu sorulara verilen yanıtlar aşağıda incelenmiştir.

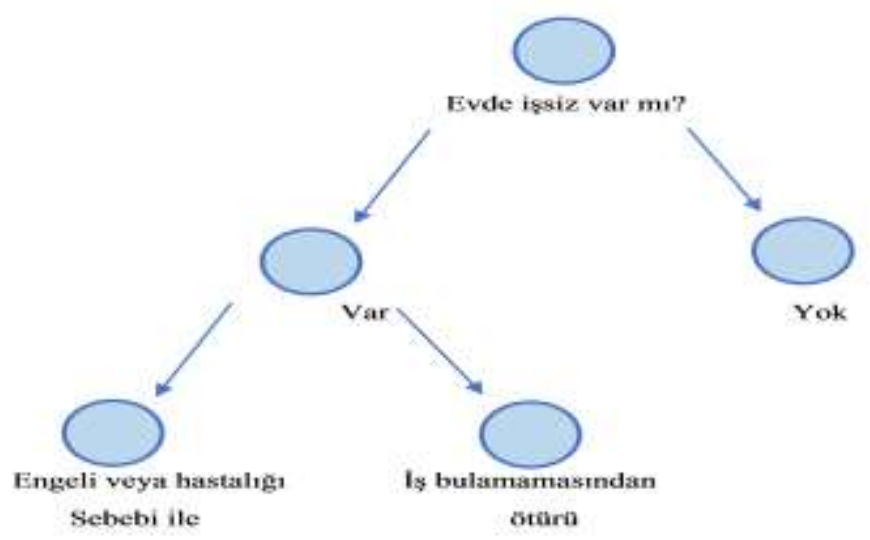

Şekil 1: Hanede Çalışma İsteğine Sahip Bireyin İstihdam Durumu 
Şekilde de görüldüğü üzere hanede işsiz bireyin bulunmasının nedeni olarak; iş bulamamasından ötürü ve engelli veya hastalık sebebi ile olduğu gösterilmiştir (Şekil 1). Görüşmelerde - evde işsiz var mı? sorusu yöneltildiğinde bir bireyin cevabı şu şekildedir;(E.T.) Kadın (anne): "Ben ev hanımıyım, önceden paketlemede çalışıyordum birakmak zorunda kaldım şimdi ev hanımıyım. "hanede bulunan baba konumunda olan sadece erkeğin çalıştığı aileler de bulunmaktadır. Bu konuda bir görüşmecinin verdiği yanıt şu şekildedir; (E.P.) Kadın (anne): “Ben çalışmıyorum, kocam çalışıyor bir tek. Hurdaya gidiyor."

Çalışan eşlerine destek olmak amacı ile eşleri ile beraber çalışarak onlara yardım eden kadınların bulunduğu hanelerin de olduğu D.T.'nin verdiği; (D.T.) Kadın (anne): "Yok, eşim servis çekiyo ben de bakkalda duruyom. " yanıttan anlaşılmaktadır. Hanedeki çalışma çağındaki bireylerin işsiz olduğu, bedenlerinde bulunan engellilik halinden dolayı çalışamayan babaların olduğu hanelerde anneler evin geçimine katkı sağlamaktadır. Bunu şu yanıttan anlamak mümkündür ; (G.Y.) Kadın (anne): "Kimse çalışmıyor evde. Bak ben çorap satıyorum öyle çalışıyorum. Kocam da görümcem de çalışmıyor. Işs yok güç yok nerde çalışsınlar. Eşim gözünden rahatsı (engelli) onun için çalı̧̧mıyor. "

Tablo 2: Hane Gelir Seviyesi ve Yardım Alma Durumu

\begin{tabular}{ccc}
\hline & $\begin{array}{c}\text { Belediyenin Verdiği Gıda ve Kömür } \\
\text { Yardımını Alıyor }\end{array}$ & Bir Yardım Almıyor \\
\hline Asgari Ücret Altı & 5 & 1 \\
Asgari Ücret & 1 & 6 \\
Asgari Ücret Üzeri & 0 & 2 \\
\hline
\end{tabular}

Hanelerde bir kurumdan veya şahıstan yardım alma durumu hane gelirine göre değişikliğe uğramaktadır. Tabloda görüleceği üzere asgari ücret seviyesi ve bu seviyenin üzerinde geliri olan haneler herhangi destek yardım almamaktadır. Asgari ücret seviyesinin altında gelire sahip haneler ise sosyal yardım almaktadır (Tablo 2). Görüşme yapılan bireylerden olan R.K ve İ'den bu konuda şu yanıtlar alınmıştır; (R.K.) Kadın (anne): "Belediyeden kömür yardımı alıyoz. 41 kart alıyom. İzmit belediyesinden yardım vermediler. Yetmiyor bu kartta çay allyom, şeker alyyom. Hemen doluyo 60-70 milyon (tl) “(i) Kadın (babaanne): "Belediye gida yardımı verdi bize 41 kart. Hep 60 lira çıklyordu. 9 kişi yani onlan nolacak. "Bu bulgulardan hareketle, yoksulluğun nedeninin tembelliğe bağlı olmadığ anlaşılmıştır.

\subsubsection{Hesabını Bilememek}

Hane gelir-giderinin tutarsız olması hane sahiplerinin hesabını bilemediğine işaret etmektedir. Gelir ve giderin birbiri ile örtüşmemesi halinde geçim darlığı ortaya çıkmaktadır ve bunun sonucunda yoksulluk olgusu meydana gelmektedir.

Tablo 3: Hane Gelir Seviyesi ve Gider Durumu

\begin{tabular}{ccccccc}
\hline & Diğer & Ĕgitim & Fatura & Gıda & Kira & Să̆lık \\
\hline Asgari Ücret Altı & 3 & 1 & 1 & 5 & 1 & 1 \\
Asgari Ücret & 0 & 0 & 4 & 3 & 0 & 1 \\
Asgari Ücret Üzeri & 0 & 0 & 2 & 0 & 0 & 0 \\
\hline
\end{tabular}

Evin gider kalemi genellikle gelire göre farklılığa uğramaktadır. Yukarıda bulunan tabloya bakılacak olunursa asgari ücret seviyesinin altında geliri olan hane giderlerinin gida kaleminin ağırlıklı olduğu, bir üst seviye olan asgari ücret seviyesinde geliri olan hanelerin ise giderlerinin fatura ve gida odaklı olduğu görülmektedir (Tablo 3). Bu temada sorulan soruya E.P ve O 'nun verdiği yanıtlar ise şu şekildedir; (E.P.) Kadın (anne): "En çok mutfağa gidiyo. Normal de yakacak veriyor belediye ama bu sene vermediler. Kendim aldım yakacağımı bu sene. “(O) Kadın (babaanne): "Borçlara gidiyor en çok para, dügü̈n yaptık onların borçları." 


\subsubsection{Aile Hayatının Düzensizliği}

Ailelerin birbirinden kopuk bir şekilde yaşam sürmeleri yoksulluğun nedenlerinden biridir. Önceden olan geniş aile yapısı günümüzde varlığını yitirmiştir ve çekirdek aile yaygınlaşmıştır. Zamanla bu çekirdek ailenin yapısında bozulmalar görülmektedir (Yusufoğlu ve Kızmaz,2012:30Şensen, 2014: 157). Aile hayatının düzensizliği temasında, hanede bulunan çocukların okula başlama yaşı, bu yaştan geç başladıysa ne sebeple böyle bir durumun olduğu üzerine sorulan sorular aşağıda incelenmiştir.

Tablo 4: Hane Gelir Seviyesi ve Çocuğun Okula Başlama Zamanı

\begin{tabular}{ccc}
\hline & Geç Başladı & Zamanında Başladı \\
\hline Asgari Ücret Altı & 1 & 5 \\
Asgari Ücret & 3 & 4 \\
Asgari Ücret Üzeri & 0 & 2 \\
\hline
\end{tabular}

Okula gidecek yaşta olan çocukların okula vaktinde başlamadığı tabloda görülmektedir. Buna rağmen okula vaktinde başlayan çocukların oranı daha yüksektir. (Tablo 4). Çocuklar okula zamanında başladı mı? Sorusuna, E.P. ve D.T. çocukların okula zamanında başladığı yanıtını vermiştir. (E.P.) Kadın (anne): "7 yaşııda, zamanında başladı." (D.T.) Kadın (anne): "5,5 yaşında başladı. Erken başladı. Adı çıktı listede l'e gitti 6 yaşına yakın olduğu için. Baya zorluk çekti ilkten. Kavrama konusunda. "Okula geç başlayanların ise neden geç başladığı ile ilgili sorulan soruya verilen yanıtlar aşağıdaki tabloda yer almaktadır (Tabo 5).

Tablo 5: Hane Gelir Seviyesi ve Çocuğun Okula Geç Başlama Sebebi

\begin{tabular}{ccc}
\hline & Maddi Durumdan Ötürü & $\begin{array}{c}\text { Mevsimlik İş İcin Gidilen Yerden } \\
\text { Geç Gelinmesi }\end{array}$ \\
\hline Asgari Ücret Altı & 1 & 0 \\
Asgari Ücret & 2 & 1 \\
Asgari Ücret Üzeri & 0 & 0 \\
\hline
\end{tabular}

Okul çağında ilköğretime başlayacak olan çocuğun vaktinde okula başlamamıştır. Buna neden olarak ise tabloda da gözlenen maddi yetersizlikler ve mevsimlik işçi olarak gidilen bölgelerden geç dönülmesinden ötürü olduğu görülmektedir (Tablo 5). Sorulan soruya Ş.B ve Y.T. şu cevapları vermişlerdir: (Ş.B) Erkek (baba): "Biraz geç başladılar okula. Domates toplamaya gitmiştik Çanakkale'ye oradan geç geldik o yüzden geç başladılar." (Y.T.) Erkek (baba): "5-6 yaşlarında başladı biri, diğeri 7 yaşında başladı. "

\subsection{4. Çok Çocuk Sahibi Olmak}

Hanedeki çocuk sayısının fazla olmasının yoksullukla ilgili olduğu araştırmalar sonucunda anlaşılmıştır (Şenses, 2014: 159). Yoksulluğun diğer bir bireysel nedeni olan çok çocuk sahibi olmak teması altında okula devam eden çocukların düzenli harçlık alması ve çocukların sağlık sigortalarının mevcudiyetini öğrenmek üzere mülakat soruları sorulmuştur.

Tablo 6: Hane Gelir Seviyesi ve Çocuğun Düzenli Okul Harçlığı Alma Durumu

\begin{tabular}{ccc}
\hline & Harçlık Verebiliyor & Harçlık Veremiyor \\
\hline Asgari Ücret Altı & 1 & 1 \\
Asgari Ücret & 3 & 3 \\
Asgari Ücret Üzeri & 1 & 1 \\
\hline
\end{tabular}

Hanede bulunan kısıtlı gelir seviyesi durumu sebebi ile okul araç-gereçlerini temin edilememesinin yanında günlük harçlık verme durumu da öneme sahiptir. Tabloya görüldüğü üzere ücret seviyelerinde asgari ücret altı ve üstü seviyede olan ebeveynlerin çocuklara harçlik verme durumu eşit seviyede seyretmiştir (Tablo 6). Asgari ücretin altında geliri olan hanelerde bulunan 
çocuklar düzenli harçlık almamakta ve alması halinde dahi yeterli miktarda almadıkları görülmektedir.

Tablo 7: Hane Gelir Seviyesi ve Çocukların Sağlık Sigortasından Yararlanma Durumu

\begin{tabular}{cccc}
\hline & $\begin{array}{c}\text { Genel Sağlık } \\
\text { Sigortasından } \\
\text { Yararlanıor }\end{array}$ & Para Verip Muayene Oluyor & Sigortası Var \\
\hline Asgari Ücret Altı & 5 & 1 & 0 \\
Asgari Ücret & 3 & 1 & 3 \\
Asgari Ücret Üzeri & 1 & 1 & 0 \\
\hline
\end{tabular}

Asgari ücret seviyesinin altında gelire sahip olan hanelerdeki çalışanlar genellikle kayıt dışı olarak istihdam edilmektedirler. Bu sebeple SGK kayıtlarının ve bununla birlikte sağlık sigortalarının olmayışı dikkat çekmektedir. Çocuklar bu durumdan olumsuz şekilde etkilenmekte ve sağlık hizmeti alırken birtakım sorunlar yaşamaktadırlar. Tabloda görülmekte olan asgari ücret seviyesinin altında geliri olan hanelerde yaşayan çocukların sağlık sigortaları yok ve bu çocuklar Genel Sağlık Sigortasından faydalanmaktadır (Tablo 7). Çocukların sağlık güvencelerini incelemek adına yöneltilen verilen yanıt şu şekildedir: (R.K.) Kadın (anne): "Sigortaları yok, yeşil kartları var. "(E.P.) Kadın (anne): "Yeşil kartları var. (GSS). " Öte yandan sağlık hizmetleri birtakım nedenlerden ötürü iptal edilmiş veya bu hizmeti alamayan haneler de mevcuttur: (B.İ.) Kadın (anne): "Yok sigortalarl, para vermek zorunda kalıyoruz." (D.T.) Kadın (anne): "Sigortasl yok çocukların. Yeşil kartım vardı. Şimdi yeşil kartım iptal oldu. Eşim vergili gözüktüğü için. Hastahaneye gidince para ödeyerek muayne oluyoruz. " Bu yanıtlara göre, asgari ücret seviyesi altında geliri olan hanelerde yaşayan çocukların GSS'den yararlanmakta olduğu anlaşılmaktadır.

\subsubsection{Etnik ve Kültürrel Özellikler}

Birtakım kendi kültürlerine has özellikler taşıyan toplumların yaşadıkları yerin halkı tarafından dışlanarak istihdam alanlarından uzaklaştırılmaları ve kötü şartlara sahip işlerde çalıştırılmaları hali etnisite olarak adlandırılmaktadır (Koptekin, 2017: 75). Bundan ötürü bu insanlar yüksek gelir seviyesine ulaşmakta zahmet çekmekte ve alt gelir sağlayan işlerde istihdam edilmektedir. Bu düşünceden hareketle yoksulluğun bireysel nedenlerinden olan etnik ve kültürel özellikler teması altında Roman kültüründe yetişmelerinin çocukların eğitim hayatına olan etkisi adına soru yöneltilmiştir.

Tablo 8: Hane Gelir Seviyesi ve Roman Olmasının Çocuğa Okuldaki Etkisi

\begin{tabular}{cccc}
\hline & Bir Sorun & Etkiledi & Bu Yüzden Okulda Fiziksel \\
& Yaşanmadı & 1 & 3 \\
Şiddet Gördü
\end{tabular}

Gerçekleştirilen görüşmelerde, çocukların Roman kültüründe yetişmesinin eğitim hayatlarındaki etkisi üzerine alınan cevapta bir sorun yaşamayan çocuk sayısı düşük seviyedeyken, sorun yaşayan çocuk sayısı yüksek seyretmektedir. Bu olumsuz durumdan ötürü fiziksel şiddet dahi gördükleri tabloda görülmektedir (Tablo 8). Mülakatlarda, çocuğun Roman olması eğitimini etkiliyor mu? Sorusunu Ş.B. şu şekilde cevaplandırmıştır: (Ş.B.) Erkek (baba): "Dışlanma oluyor okulda. Alıştık sonradan ama çocuklara 1-2 kere psikolojik baskı uygulaninca okula gidesi gelmiyor ki. Kızım da bu yüzden gitmiyor okula. Mesela ben Çanakkale'de çalışıyordum. Bizi görünce oo Romanlar çingeneler geldi diyorlard h hep. E o çocuk okula gider mi. Gidip ögretmenleriyle de müdürlerine de dile getirdim. " Öte yandan başlarda dışlanılsa da sonraları bu sorunun düzeldiği haneler de vardır. Bu da D.T. nin verdiği: (D.T.) Kadın (anne): "Evet etkiledi. Başlayınca, bayanlar tepki gösterdi, veliler. İstemediler. Bizi dışladılar birazcık. Tanıyınca beni, çocuğumu bizi de aldılar yanlarına. " yanıtından anlaşılmaktadır. Hiç dışlanmaya maruz kalmamış, 
okul ortamında sorun yaşamamış haneler de mevcuttur. R.K. bu gruptadır: (R.K.) Kadın (anne): "Yok olmadı. Öğretmeni çok seviyo onu. "

\subsubsection{Eğitim Durumu}

Eğitim, bireyin çalışabilme yeteneğini ve düzeyini belirleyen bir öğedir. Eğitim almış bir kimsenin iş imkanı ve istihdam edilebilme özelliği oluşmaktadır (Özdemir, 2014:21). Bu düşünce doğrultusunda, eğitim durumu teması altında çocukların hane gelirine desteği, çocukların evlilik yaşı ve kız çocuklarının eğitimi hakkında düşüncelerini öğrenmek amacıyla sorular yöneltilmiştir.

Tablo 9: Hane Gelir Seviyesi ve Roman Çocuğun Aile Geçimine Katkı Sağlama Görüşü

\begin{tabular}{ccc} 
& Katkı Sağlaması Gerekli & Hayır, Okusun \\
\hline Asgari Ücret Altı & 4 & 2 \\
Asgari Ücret & 6 & 1 \\
Asgari Ücret Üzeri & 0 & 2 \\
\hline
\end{tabular}

Çocukların eğitim almasının yanı sıra, okula devam etmeyerek aile geçimine katkı sağlaması gerektiği düşüncesi hakimdir. Tabloda görüleceği üzere, asgari ücret seviyesi ve altında geliri olan haneler, çocukların hane gelirine destek olması gerektiği yönünde düşünceye sahiptir. Asgari ücret seviyesinin üzerinde geliri olan haneler ise çocukların okumasının gerekliliği düşüncesindedir (Tablo 9). Bu temada yöneltilen sorulara verilen yanıtlar şöyledir : (D.T.) Kadın (anne): "Zamanı geldiğinde ailesine bakmalı yani.. Okuldan çıtı̆ı̆ında mesela 17-18. Lise bitince." (Ş.B.) Erkek (baba): "Oğlanlarda bulunması lazım.18-19 yaşında olması lazım. En azından kendini savunbileceği kendini ifade edebileği yaşa geldikten sonra." D.T. ve Ş.B.'nin yanıtları ise, çocukların hane gelirine katkıda bulunmasını daha çok üniversite seviyesine gelinmesi halinde doğru olacağı düşüncesini yansıtmaktadır. Lise eğitiminden sonra hane gelirine katkı sağlanması gerekli görülmektedir.

Tablo 10: Anne, Baba, Babaanne ve Dedenin Çocukların Evlenme Yaşı Konusundaki Görüşü

\begin{tabular}{ccc}
\hline & 18 Yaşından Önce Evlenmeli & 18 Yaşından Sonra Evlenmeli \\
\hline Kadın (Anne) & 1 & 5 \\
Erkek (Baba) & 0 & 4 \\
Kadın (Babaanne) & 1 & 1 \\
Erkek (Dede) & 0 & 1 \\
\hline
\end{tabular}

Görüşülen hane bireylerine çocukların evlilik yaşları konusunda soru yöneltilmiştir. Genel olarak üç gelir düzeyinde de yanıtlar, çocukların 18 yaşından sonra evlenmeleri üzerinedir. $\mathrm{Bu}$ soruyu 2 kişinin yanıtlamaması sebebi ile tabloda 13 hanenin cevabı bulunmaktadır (Tablo 10). Yöneltilen soruya şu şekilde yanıtlar verilmiştir: (Y.T.) Erkek (baba): "Tam 18 yaşsıdan sona evlenmeli 17 desen haram 19 desen de haram çünkü ehliyetini de alır, nikahını da yapar, çocuk da olsa hastahanede sıkıntı olmaz. Ama sen napıyosun gidiyosun 14 yaşında çocuğu evlendiriyorsun 1 sene sonra çocuk yapıyo gidiyon hastahanede uğraşlyorsun. " Bu yanıttan da anlaşılmaktadır ki erken yaşta evlenilerek çocuk sahibi olunması halinde resmi işlemlerde sorunlarla karşılaşılmaktadır. Yine aynı görüş̧e olan Ş.B. (Ş.B.) Erkek (baba): "Bence büyüsün de evlensinler. Biz evlendik de noldu erken yaşta. 14 yaşında evlendim 15 yaşımda 2 çocuk babası oldum. 15 yaşımda buradan çıktım 37 yaşıma kadar İstanbul'da yaşadım. " yanıtıyla erken yaşta çocuk sahibi olmanın sorun teşkil ettiğinden söz etmektedir. Bu görüşlerden hareketle hane bireyleri çocukların erken yaşta evlendirilmesine karşı oldukları anlaşılmaktadır. Fakat mahalle genelindeki söylemler doğrultusunda, erken yaşta evliliğe olumsuz bakılsa da çocukların küçük yaşta evlendirilmeleri söz konusudur. 

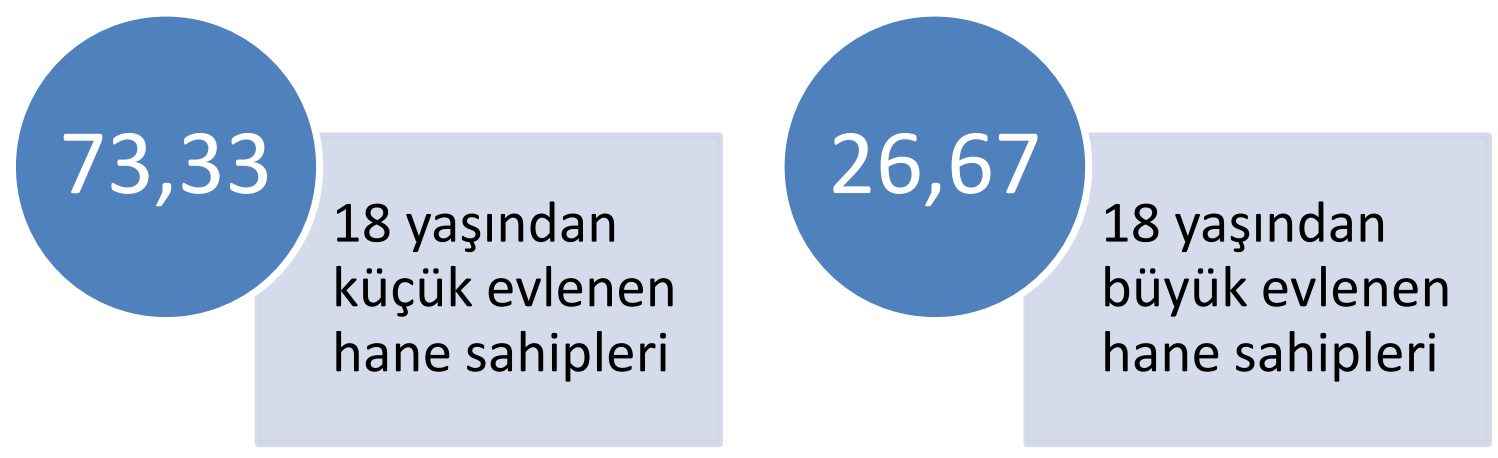

Şekil 2: Görüşülen Hane Sahibi Bireylerin Evlilik Yaş1

Roman topluluğunda genellikle erken yaşta evlenme durumu söz konusudur. Yukarıdaki şekilde de görüldüğü üzere hane bireyleri ile yapılan mülakatlarda 18 yaşından önce evlenen bireyler yüzdelik dilimin \%73,33 lük kısmını kapsamaktadır. 18 yaş ve sonrasında evlenenler ise \%26,67 lik bir bölümde yer almaktadır (Şekil 2). Araştırma sahası olan mahallede, çocuk yaşta gerçekleşen evliliklerin devam ettiği mahalleli tarafından söylenmektedir. Bu nedenle, ailelerde tedirginlik söz konusu olduğu için ortaöğretim eğitimini tamamlayan kız çocuklarının okula gönderilmesi konusunda çekinik tavır sergilemektedirler ve bu seviyeye gelmiş olan kız çocuklarını okula göndermemektedirler (Tablo 11-12). Bu görüşlerden hareketle hane bireyleri çocukların erken yaşta evlendirilmesine karşı oldukları anlaşılmaktadır. Fakat mahalle genelindeki söylemler doğrultusunda, erken yaşta evliliğe olumsuz bakılsa da çocukların küçük yaşta evlendirilmeleri söz konusudur.

Tablo 11: Anne ve Babanın Kız Çocuğunun Eğitim Konusundaki Düşüncesi

\begin{tabular}{ccc}
\hline & $\begin{array}{c}\text { Okutulmuyor, Kaçırdıkları İçin } \\
\text { Okula Gönderilmiyor }\end{array}$ & Okutmak İstiyor \\
\hline Kadın (Anne) & 0 & 6 \\
Erkek (Baba) & 3 & 0 \\
\hline
\end{tabular}

Burada, hanelerdeki görüşmecilerden anne ve babalarının görüşlerine yer verilmiştir. Diğer haneleri temsil eden anneanne, babaanne ve dedelerin görüşlerine bu tabloda yer verilmemiştir. Bu nedenle, toplam 9 hane ile yapılan görüşmeler tabloya yansıtılmıştır. Kız çocuklarının eğitimi ile ilgili yöneltilen soruya "okutmak istiyorum" cevabı çoğunluğun cevabıyken, kız çocuklarını evlenmek için başkalarınca kaçırılma durum olduğu için aileler kızları okula gönderememektedir. Görüşme yapılan hanelerdeki anneler kız çocuklarını okutmak istediklerini söylerken, babalar ise bu sorundan ötürü okula göndermediklerini belirtmişlerdir (Tablo 11). Bu konuda mülakat yapılan hanelerden biri şu cevabı vermiştir; (B.A.) Erkek (dede): "18'i de geçsin 20-25 yaşında gitsin ama bizim mahalle bırakmıyor. Bizim mahalle kötü, kaçırlyorlar kızları 13-14 dedin mi. Kaçak kızı kimse geri de vermiyor. Böyle sorunlar yaşıyoruz. " şeklindeki yanıtında ne kadar kız çocuklarının eğiitme devam etmeleri düşüncesi hakim olsa da, gerçek hayatta yani mahallede gerçekleşen çocuk yaşta kaçırılmak suretiyle evlendirilme sorunu yaşanması sebebi ile bu düşüncenin bir anlam ifade etmediği görülmektedir.

\subsubsection{Göç}

Yoksulluğun nedenlerinden biri de kırdan kente göç ve farklı sebeplerle yapılan göçler görülmektedir (Şenses, 2014:161). Yoksulluğun bireysel nedenlerinden biri olan göç temas1 altında yerleşik bir hayat veya göçebe bir hayata sahip olup olmadıklarını ögrenmek amacı ile sorular yöneltilmiştir. 
Tablo 12: Hane Gelir Seviyesi ve Hane Sahiplerinin Göç Durumu

\begin{tabular}{cccc}
\hline & $\begin{array}{c}\text { Başka Bir Yerden } \\
\text { Göç Etmiş }\end{array}$ & $\begin{array}{c}\text { Mevsimsel Göç } \\
\text { Hareketliliği }\end{array}$ & Yerleşik \\
\hline Asgari Ücret Altı & 1 & 3 & 3 \\
Asgari Ücret & 1 & 1 & 4 \\
Asgari Ücret Üzeri & 0 & 0 & 2 \\
\hline
\end{tabular}

Yapılan görüşmelerde hane sahiplerine yöneltilen sorulara çoğunlukla mevsimsel işçi olmaları sebebi ile mevsimsel göç hareketliliğinde bulundukları cevabı alınmıştır. Bu hane bireyleri genellikle mevsimsel göç etseler de yerleşiklerdir. Asgari ücret seviyesinde geliri olan hanelerin verdiği cevaplardan göç etmiş oldukları anlaşılmaktadır. Hiçbir şekilde bir göç hareketliliğinde bulunmamış ve mevsimsel işçi olmayanların sayısı azınlıktadır (Tablo 12). Bu konu ile ilgili yöneltilen soruya şu şekilde cevaplar gelmiştir: (R.K.) Kadın (anne): "Mevsim iş̧̧iliği yapıyoz. Findlk toplamaya gidiyoz." (İ.O.) Kadın (anne): "Çanakkale'ye gidiyoruz bazen. 1-2 ay kallyoz orda domates topluyoz. " Göç hareketliliğinin temel sebebi olan tarım işçiliğinin yanında bohça alım-satım işleri için de mevsimsel göç gerçekleşmektedir. Görüşülen hane bireylerinden D.T.'nin bohça sebebi ile yaptığı göç hareketliliğine artık son verdiği; (D.T.) Kadın (anne): "Önceden gidiyorduk. 10 sene önce evlenmeden önce. Memleket memleket geziyorduk. Annemiz bohça yapıyordu. Satıyorduk. Tül-perde öyle şeyler yapıyorduk. Artık yok kalmadı öyle. "bir diğer görüşülen hane bireylerinden olan Y.T.'nin bu işe devam ettiği; (Y.T.) Erkek (baba): "Gidiyoruz, İstanbul'a gidip geliyorum çeyizlik eşya satma için malzeme alıyoz. Ama yerleşiğiz." Yanıtından anlaşılmaktadır.

\subsection{Roman Çocuk Yoksulluğunun Toplumsal Nedenleri}

\subsubsection{Kapitalizm ve Küreselleșme}

Kapitalizm; modernleşme, tek tipleşme ve akabinde sınıfsal eşitsizlikleri beraberinde sürüklemektedir (Sipahi, 2006:176). Küreselleşme ise kapitalizmin her alana girmesine neden olmuştur ve devamında toplumsal sınıf anlayışının arasındaki mesafelerin git gide genişlemesine yol açmıştır (Yusufoğlu ve Kızmaz, 2012: 27). Yoksulluğun toplumsal nedenlerinden biri olan kapitalizm ve küreselleşme teması altında çocukların ailenin karşılayamayacağı şeyler istemesi ve hanede çalışan bir birey yok ise geçim kaynağının ne olduğu yönünde sorular yöneltilmiştir.

Tablo 13: Çocukların Pahalı Şeyler İstemesi Durumu

\begin{tabular}{ccc}
\hline & İstiyor & İstemiyor \\
\hline Asgari Ücret Altı & 5 & 2 \\
Asgari Ücret & 2 & 4 \\
Asgari Ücret Üzeri & 1 & 1 \\
Asgari Ücret Üzeri & 1 & 1 \\
\hline
\end{tabular}

Sorulan mülakat sorularına alınan yanıtlardan asgari ücretin altında geliri olan hanelerde yaşayan çocukların pahalı şeyler istediği, asgari ücret seviyesinde geliri olan hânelerdeki çocukların ise istemediği sonucu tabloda görülmektedir (Tablo 13). Verilen yanıtlar şu şekildedir;(B.A.) Erkek (dede): "İster illa da ama daha istemediler. Ben bisiklete karşılyım almam zaten çok tehlikeli arabalar geliyor. "(R.K.) Kadın (anne): "Bazı istiyo, bazı istemiyo." (E.P.)(Kadın) (anne): "Yok istemiyorlar. "

Tablo 14: Hane Gelir Seviyesi ve Ailenin Geçim Kaynağı

\begin{tabular}{cccc}
\hline & Bohçacılık & Demircilik & Hurdacılık \\
\hline Asgari Ücret Altı & 4 & 0 & 0 \\
Asgari Ücret & 2 & 1 & 1 \\
Asgari Ücret Üzeri & 1 & 0 & 0 \\
\hline
\end{tabular}


Hanede aktif olarak istihdam edilmeden gelir getirilmemesi halinde ne türlü gelirleri olduğu ve hane bireylerin nasıl geçindiğini öğrenmek amacı ile yöneltilen soruya, çoğunlukla bohçacılık yanıtı alınmıştır. Burada belirtilen ücret düzeyleri hanenin toplam geliri şeklinde düşünülerek yerleştirilmiştir. Fakat asgari ücret altında gelire sahip hane bireylerinin hurdacılık ile uğraştı̆̆ 1 cevabı yüksek seviyededir. Bunu asgari ücret seviyesinin üzerinde geliri olan hanede de bohçacılık yapıldığı cevabı takip etmektedir (Tablo 14). Bu konu hakkında yöneltilen soruya şu yanıtlar alınmıştır; (R.K.) Kadın (anne): "Kocam hurdacılık yapıyo. Öyle kazanıyoz." (E.P.) Kadın (anne): "Kocam hurdaya gidiyo. Geçim kaynağımız o. Bir de belediyeden 41 kart yardımı ve çocuk parası alıyoz." Diğer yandan Y.T.' nin verdiği; (Y.T.) Erkek (baba): “Bohçacılık yapıyor eşim. " yanıtından eşinin bohçacılık yaparak hane geçimini sağladığı anlaşılmaktadır. Hanede düzenli gelir getirecek devamlı bir işte çalışan bireyin olmaması halinde geçimlerini sağlamak amacı ile bohçacılık, hurdacılık ve demircilik işi ile ilgilenmektedirler.

\subsection{Nüfus Artışı}

Nüfus artışının yoksulluğun bir nedeni olmasında köyden kente göçün artış göstermesi aktif rol oynamaktadır. Öte yandan kent merkezlerinde olumsuz koşulların oluşumu, kötü alışkanlıklara sahip insanların artış göstermesi, tehlike ortamının meydana gelmesi ve çevre kirliliğinin ve düzeninin bozulmasının bir nedeni olarak nüfus artışı görülmektedir (Şenses, 2014: 154-156). Nüfus artışı teması altında şehrin çocuklar açısından tehlikeli olma durumu hakkındaki düşüncelerini öğrenmek amacı ile yöneltilen soruya verilen yanıtlar aşağıda incelenmiştir.

Tablo 15: Hane Büyüklerinin Çocuklar Yönünden Mahallenin Tehlikeli Olması Konusundaki Görüşü

\begin{tabular}{ccc}
\hline & Burası Tehlikeli & Tehlikeli Bir DurumYok \\
\hline Kadın (Anne) & 2 & 3 \\
Erkek (Baba) & 3 & 0 \\
Kadın (Babaanne) & 2 & 3 \\
Erkek (Dede) & 0 & 0 \\
\hline
\end{tabular}

Araştırma sahası olan Tavşantepe mahallesi, İzmit ilçesi genelinde olumsuz yönde anılmaktadır. Görüssmelerde konu ile ilgili yöneltilen soruya mahallenin tehlikeli bir bölge olduğu yanıtı çoğunlukta alınan bir yanıttır. Görüşülen hane bireylerinden baba olan görüşmeciler mahallenin tehlikeli olduğunu düşünenler arasında başı çekmektedir. Öte yandan anne ve babaannelerle gerçekleştirilen mülakatta mahallenin tehlikeli bir ortama sahip olduğunu düşünenlere karşın bir tehlike olmadığını düşünenler de mevcuttur (Tablo 15). Bu tema altında yöneltilen soruya şu cevaplar verilmiştir: (I) Kadın (babaanne): "Illlâ ki korkuyoruz. Burda böyle tehlikeler olmaz. Geziyor çocuklar. Bizim mahallede böyle şeyler olmaz Allah'a şükür. "şeklinde verilen yanıtta mahallenin tehlike arz etmeyen bir yer olduğunu düşünen bir kesimin olduğu anlaşılmaktadır. Diğer yandan; (Ç.B) Kadın (babaanne): "Bir yaştan sonra kaçırılma olayları oluyor, korkuyoruz tabi öyle şeylerden." (D.T.) Kadın (anne): "Her yerden korkuyoruz. Hep gözümün önünde olsan istiyorum dışarı salmiyorum. " yanttlarından tehlikenin olduğunu düşünen bir kesimin varlığının çoğunlukta olduğu anlaşılmaktadır. Mahallede en önemli sorunlardan birisi de kızların kaçırılma olayı olduğu için B.İ ve B.A.; (B.İ.) Kadın (anne): "Yok tehlike burada. bi kaçırma olayları var ondan da çocuklara okula temkinli gidiyor başka da bi şey yok" (B.A.) Erkek (dede): "Yok bi sıkıntı mahallede. Bir sıkıntımız kız kaçırma olayı, başka bir şey yok. " gibi sadece kaçırılma olayını tehlikeli gören hane sahipleri de bulunmaktadır. Bu yanıtlar doğrultusunda, mahallede bulunan bireylerin iyi insanlar olduğunu ve mahallenin tehlike barındırmadığını düşünen görüşmecilerin yanısıra tehlikeli ortamın olduğunu düşünen hane sahipleri çoğunluktadır. Bu nedenle mahallenin çocuklar açısından tehlikeli olduğu görüşü sonucuna varılmaktadır. 


\subsection{3. İş Piyasaları}

İş piyasalarında meydana gelen değişim ve gelişimler, işverenler tarafından artık isithdamı gerekmeyen özellikteki çalışanların işten çıkarılmalarına, o sektörde ve alanda bilgi-beceri sahibi çalışanların artık istihdam edilmemesine sebep olmaktadır (Özdemir, 2014: 21). İş piyasaları teması altında aile mesleği olrak icra edilmeye devam edilen bir işin o mevcudiyetini incelemek amacı ile yöneltilen sorular aşağıda incelenmiştir

Tablo 16: Hane Gelir Seviyesi ve Hanenin Aileden Kalan Meslekleri Devam Ettirme Durumu

\begin{tabular}{cccc}
\hline & Bohçacılık & Demircilik & Hurdacılık \\
\hline Asgari Ücret Altı & 4 & 0 & 0 \\
Asgari Ücret & 2 & 1 & 1 \\
Asgari Ücret Üzeri & 1 & 0 & 0 \\
\hline
\end{tabular}

Yapılan görüşmelerde hala ve daha önce aileden kalma mesleklerin devam edilme durumunu öğrenmek amacı ile sorulan "Ailenizden kalan hâlâ yapmakta olduğunuz bir meslek var mı?" sorusuna verilen yanıtlarda hurdacılık ve bohçacılık meslekleri ön planda ola ve tükenmekte olan mesleklerdir. Daimi bir işte çalışan bireyin olmadığı haneler de bu meslekleri sürdürmektedir ve alınan yanıtlar aile mesleğini sürdürenlerle aynı çıkmıştır (Tablo 16). Bu durum sorulan soruya; (E.P.) Kadın (anne): "Bohçacılık yapıyorduk. Şimdi yapamıyom "(Y.T.) Erkek (baba): "Eșim arada sırada bohçaya gidiyo. Çeyizlik şeyler satıyo." şeklinde gelen cevaplarla gösterilmiştir. Öte yandan gelir seviyesi asgari ücretten yüksek olan meslekler ilgilenen hanelerde de bohçacıllk gibi aileden kalma mesleklere devam edildiği şu yanıttan anlaşılmaktadır: (B.İ.) Kadın (anne): "Eşim servisçi ama ben de aslında bohçacılık yapıyorum ama şimdi hamile olduğum için gidemiyorum. “I.O.'nun eskiden hane geçimlerini bohçacılık ile gerçekleştirmektedirler fakat şimdi devam etmedikleri; (İ.O.) Kadın (anne): "Daha önceden bohçacılık yapıyorduk da şimdi yapmıyoruz. "şeklinde verilen cevaptan anlaşılmaktadır. D.T. ise önceden demircilik yaparken şimdi bu mesleğin artık yapılmadığını şu şekilde iletmektedir: (D.T.) Kadın (anne): "Önceden demircilik yapıyorduk işte. Annem bohçacılık yapıyordu. Ben de yapıyordum gençken. Bu yanıtlardan aileden kalma mesleklerin tükendiği, devam edenlerin ise başka geçim kaynağ 1 olmayışından ötürü bu mesleklere devam ettikleri anlaşılmıştır.

Araştırmanın sorularının elde edilen bulgular karşısında değerlendirilmesi, çalışmanın sonucu olarak aşağıda yer almaktadır.

\section{Sonuç}

Araştırma sahasının işsizlik durumuna bakıldığında işsizliğin yok denecek kadar az olduğu, devamlı ve düzenli gelire sahip bir işte çalışılmasa da hayatlarını idame ettirecek kadar geliri olan işlerde çalışıldığ 1 anlaşılmaktadır. Tembellik sebebi ile bir işten kaytarma veya çalışmama hâli mevcut değildir. $\mathrm{Bu}$ nedenle, araştırma sahası olan yoksulluğun, etnik özelliklerden ötürü sahip oldukları çalışma ortamlarına ve işlere yönelmek zorunda kaldıkları diğer çalışma ortamlarına alınmadıkları ve aynı zamanda eğitim eksikliği sebebi ile farklı meslek ve işlerde çalışamadıkları tespit edilmiştir. Bundan hareketle sahip oldukları yoksul yaşantının temel kaynağının tembellikten ötürü olmadığı söylenebilir.

Yapılan harcama düzeyi ve türü gelire göre değişkenlik göstermektedir. Asgari ücretin altında geliri olan hane ile asgari ücret üzerinde bir seviyede geliri olan hanenin gider ve harcama türleri farklılaşmaktadır. Her gelir düzeyindeki hanenin gelirini yine gıda olarak eğlence yönünde kullanıldığını söylemek mümkündür. Daimi bir gelir mevcut olmadığı gibi gelen parada düzenli olarak harcanmamaktadır. Yaşanılan yoksulluğun, hesapsızca yapılan harcamalardan kaynaklandığı anlaşılmıştır. Para birikimi olmadığı ve buna bağlı olarak da gelen paranın hesapsızca harcanması sebebi ile gelir-gider dengesi oluşmamıştır. $\mathrm{Bu}$ sebeple içinde bulunulan yoksulluğun 
nedenlerinden birinin hane büyüklerinin hesabını bilememelerinden ötürü yaşandığı gözlemlenmiştir.

Yapılan araştırmada, asgari ücret seviyesi altında geliri olan haneler, yaz aylarında mevsimsel işçi olarak çalışmaktadırlar. Bu aileler, farklı şehirlere tarım işçisi adı altında mevsimsel olarak göç hareketliliğinde bulunmaktadır. Bu haraketlilik, yaz aylarında gerçekleştiğinden dolayı dönüşler eğitim-öğretim döneminin başlangıcından sonraki bir zamana denk gelmektedir. Bu nedenle okul çağındaki çocuklar okul açılma zamanında okula başlayamamaktadırlar. Bu durumun diğer bir neticesi olarak da okul ortamına uyum sağlama ve eğitim-öğretimden geri kalma hali söz konusu olmaktadır. Sonuç olarak bu çocukların eğitime geriden başlamalarından ötürü, okula devam etrme hususunda sorun yaşamakta ve bunun devamında okuldan uzaklaşmaktır. Ailenin içinde bulunduğu yoksulluğun çocuklara etkisi ve kısır döngü halinde devam etmesi olayı burada ortaya çıkmaktadır. Böyle durumların genellikle asgari ücret seviyesinin altında geliri olan hanelerde meydana geldiği anlaşılmıştır.

Eğitim hayatına geç atılan veya gerekli okul materyalleri olmayan çocuklar okul ortamından soğuduğu için devamsızlık yapmaktadır. Bu ihtiyaçların bir kısmını ilçe belediyesi tarafından tamamlanmaya çalışılsa da yine bazı eksikler varlığını korumaktadır. Hanede yaşayan çocuk sayısınca kaymakamlık tarafindan maddi yardım desteği sağlandığı mülakatlar sırasında anlaşılmıştır. Verilen bu nakdî sosyal yardımlar, çocuğun eğitimde devamsızlık yapması hâlinde veya babanın sigortalı bir işe girmesi ile kesilmektedir. Mülakat yapılan aileler çocuklar için verilen nakdi yardımın kesilmesi halinde bunun nedenini bilmediklerini belirtmişlerdir. Çocukların, devamsızlık yapmaları ve eğitim hayatını bırakmaları nedeninden dolayı bu desteğin kesildiği anlaşılmıştır.

Aileler eğitim konusunda yeterli bir düzeyde olamasalar da çocuklarının ileri seviyede olmasını isterler. Roman ailelerde de bu durum aynıdır. Çocuklarının kendileri gibi yaşadıkları sıkıntıları yaşamadan daha rahat bir hayata sahip olmalarını isterler. Araştırma sahasında, asgari ücretin altında gelire sahip olan hanelerdeki çocukların okula kendi istekleri ile gitmedikleri ve kız çocuklarını ise evlenmek için kaçırılmalarından ötürü bu olayın önüne geçmek adına okula aileleri tarafından gönderilmedikleri anlaşılmıştır.

Aile planlaması olmadan çocuk dünyaya getirmek, hane gelirini hesaplı kullanmamaya ve geçim sıkıntısı çekmeye sebebiyet vermektedir. Hane gelirinin aile içi birey sayısınca bölünmesi, fert başına az bir miktar düşmesine neden olmaktadır. Bu da çocukların bir takım zarurî ihtiyaçlarının karşılanmamasına sebebiyet vermektedir. Bundan ötürü çocuklar; yoksul bir hanede hayati ve içinde bulundukları çocukluk çağının getirdiği gelişimsel ihtiyaçların yoksunluğunu yaşamaktadır. Roman ailelerde bu durum kendini daha fazla göstermektedir. Yoksulluk içinde yaşayan aileler, çocukları bu yoksun ve sınırlı durum üzerine dünyaya getirmektedirler. Aileler hastalık durumunda çocukların tedavilerini tam olarak gerçekleştirememekte ve bu tedaviler SGK kayıtları bulunmadığından ötürü olumlu sonuca varmadan yarım kalmaktadır. Böyle bir durum karşısında ayni ve nakdi sosyal yardımlar devreye girmekte ve eksiklikler giderilmeye çalışılmaktadır.

Romanlar; sahip oldukları kültürel özellikler, yaşayış tarzları, fiziksel özellikleri, toplum içindeki hal ve hareketleri gibi sebeplerle toplumdan izole edilen bit topluluktur. Eğitim, sağlık, istihdam ve sosyal hayattan ötekileştirilerek uzaklaştırılmak istenmektedir. Eğitim hayatında, Roman çocuk, sınıfta bulunan Roman olmayan arkadaşının velisi tarafindan dışlanmaktadır. Karşılaştığ 1 ve içinde bulunduğu kısıtlı durum karşısında okul hayatına devam etmeye çalışan Roman çocuk bu sebeple eğitim hayatından uzaklaşmaktadır. Yapılan görüşmelerde de görüldüğ̈̈ üzere Roman çocuğun kendi isteğiyle eğitim hayatından uzaklaştı̆̆ anlaşılmaktadır. Dışlanmayan kesime bakıldığında bu hanelerin asgari ücret seviyesinin üzerinde geliri olan kesim olduğu görülmektedir. Dışlanmanın asgari ücret seviyesinin altında geliri olan hanelerdeki çocuklarda olduğu anlaşılmıştır.

Turkish Studies, 15(5) 
Roman topluluğu, göç veya mevsimsel olarak gittikleri yerlerin kültürünü alsalar dahi kendi kültürlerini yaşatmaya devam etmektedir (Altınöz,2013: 50-152). Bundan ötürü kendilerine özgü yaşam tarzları olan bu topluluğun bu özelliği gelir getirme yöntemlerini de etkilemiştir. Günlük yaşayan bu topluluk, genellikle düzenli ve birtakım kuralları olan işlerde çalışmamaktadır (Çetin, 2017:91-92). Bununla birlikte eğitim geçmişine sahip olmayan, olsa dahi Roman bireyler, genellikle istihdam edilirken olumsuz yönde değerlendirilmektedir. Araştırma sahasında görüşülen haneler çoğunlukla; servis taşımacılığı, hurdacılık ve bohçacılık meslekleri ile uğraşmaktadırlar. Servis işi yapanlar asgari ücret seviyesi ve üzeri bir gelire sahipken, hurdacılık işini yapanların ise asgari ücret altı seviyede bir gelire sahip oldukları tespit edilmiştir.

Roman çocuk, içinde bulunduğu yoksul ve yoksun ortamın etkisini okul ortamlarında daha fazla hissetmektedir. Maddi ve manevi olarak her ihtiyaçları karşılanamayan, karşılansa dahi yine bir tarafta eksikleri bulunan bu çocuklar okul ortamlarında daha fazla dışlanmaya maruz kalmaktadır. Gerçekleştirilen görüşmelerde, Roman çocuğun dışlanmasından ötürü okuldan soğuduğu, uzaklaştığı ve bunun beraberinde devamsızlık yaptığı sonucuna varılmıştır.

Göç, genellikle kırsal kesimden büyük şehirlere doğru işsizlik sebebi ile gerçekleşen bir olgudur. Roman topluluğu bugün Türkiye üzerinde belli başlı bir memleketi olmayan bir topluluktur. Bu sebeple, çok fazla konar-göçer yaşayan ve hareket halinde olan bir yapıya sahiptir. Yapılan çalışma da görüşülen aileler yerleşik düzeyde yaşamaktadır. Fakat mevsimsel göç hareketliliğinde bulunarak senenin belli zamanlarında farklı şehirlere gitmektedirler. Daimi işe sahip olanlar bu sınıfta yer almamaktadır. Çoğunlukla, günlük işlerde çalışan kesimin mevsimsel olarak göç hareketliliğinde bulunduğu tespit edilmiştir. Yoksulluk ve işsizlik sebebi ile Kocaeli şehrine göç etme durumu olmadığı anlaşılmıştır.

Kapitalizm ve beraberinde getirdiği küreselleşme, dünyayı tek tipleştirmeyi amaçlamaktadır ve alt tabaka denilen düşük gelir seviyesini yok etmeyi amaçlamaktadır. Bugün yoksul bir çocuk gerekli olan ihtiyacına belli imkânsızlıklar sebebiyle ulaşamazken küreselleşme ile ihtiyaç ve istekleri değişkenlik göstermektedir. Çocuklar, çocukluk çağlarının getirisi olarak farklı ve pahalı isteklerde bulunabilmektedirler. Yapılan görüşmelerde, hanelerdeki çocukların ailenin karşılayamayacağı isteklerde bulunmadıkları tespit edilmiştir.

Nüfusun artması, mevcut nüfusun yerine geçecek daha düşük ücretle istihdam edilecek işçilerin bulunması, nüfus artışının yoksulluğun bir sebebi olarak görülmesine neden olmaktadır. Farklı yerlerden gelmiş olan insanlar, topluluklar ve farklı kültürdeki insanların yerli halkın ve orada uzun süredir var olan toplumların içine girmesi ile tehlike arz etmektedir. Bu insanların kötü alışkanlıklara ve olumsuz davranışlara sahip olmaları gittikleri yerlerdeki huzur ortamına balta vurulmasına sebep olabilmektedir. Görüşmelerin yapıldığı mahallede, çocukları tehdit edebilecek tehlike unsurunun varlığı ailelerin görüşleri ile tespit edilmiş̧tir. Mahallede tehlike arz eden bir kesimin var olduğu anlaşılmıştır.

Ailelerinden aldıkları bilgi birikimi ve kazandıkları mesleki eğitim ile geçimini sürdüren pek çok aile gelişen teknoloji yüzünden işsiz kalmış ve farklı iş kollarında iş bulmaya yönelmiştir. Roman mesleği olarak tanınan pek çok meslek bu nedenle yok olmuştur. Hala kendi halinde üretim yapmaya çalışan emekçi üreticiler de mevcuttur. Araştırma alanında artık eski mesleklerin icra edilmediği ve bu mesleklerin ortadan kalkması ile bu meslekleri yapan ailelerin, servis veya hurda işlerine yöneldikleri tespit edilmiştir. 


\section{Kaynakça}

Aile ve Sosyal Politikalar Bakanlığı (2016). Roman Vatandaşlara Yönelik Strateji Belgesi 20162021. Aile ve Toplum Hizmetleri Genel Müdürlüğü.

Alp, H. (2015). Medyada Nefret Söylemi ve Çingene Toplumuna Yönelik Ayrımcı Söylemin Suça Dönüşme Süreci. Doktora Tezi, İstanbul Üniversitesi.

Altıöz, İ. (2013). Osmanlı Toplumunda Çingeneler. Türk Tarih Kurumu Yayınları.

Asseo, H. (2004). Çingenler Bir Avrupa Yazgısı. TÜRKAY, Orçun (Çev.), Ofset Yayınevi.

Aşkın, U. (2012). Çingeneler ve Sosyal Politika - 3.Çalışma Ortamı Dergisi. s. 122, 20-22.

Aytaç, Ö. (2005). Kapitalizm ve Boş Zaman. Eskişehir Osmangazi Üniversitesi Sosyal Bilimler Dergisi, 6(1), 1-22.

Barrientos, A. ve Dejong, J. (2006). Reducing Child Poverty with Cash Transfers: A Sure Thing. Development Policy Review, 24(5), 537-552.

Başel, H. (2007). Türkiye'de Nüfus Hareketlerinin ve İç Göçün Nedenleri. Sosyal Siyaset Konferanslart Dergisi, 0(53), 515-542.

Başkurt, İ. (2003). Gençlik, Madde Bağımlılığı ve Korunma Yolları (Psiko-Sosyal Bir Yaklaşım). İstanbul Üniversitesi, İlahiyat Fakültesi Dergisi, 0(8), 73-114.

Baulch, B., and Mcculloch, N. (1998). Being Poor and Becoming Poor: Poverty Status and Poverty Transitions in Rural Pakistan. IDS Working Paper 79, Brighton: IDS

Berg, B.L. and Lune, H. (2019). Sosyal Bilimlerde Araştırma Yöntermleri. ARI, Asım (Çev.), Eğitim Yayınev.

Buğra, A. (2018). Kapitalizm, Yoksulluk ve Türkiye'de Sosyal Politika. İletişim Yayınları, 9. Bask1.

Çeken ve diğerleri. (2008). Eşitsizliği Derinleştiren Bir Süreç Olarak Küreselleşme ve Yoksulluk., Cumhuriyet Üniversitesi İktisadi ve İdari Bilimler Dergisi, 9(2), 79-95.

Çetin, B. I. (2017). Kimlikleriyle Romanlar: Türkiye'deki Roman Vatandaşlara Yönelik Sosyal İçerme Ulusal Strateji Belgesi ve Birinci Aşama Eylem Planı'nın Değerlendirilmesi. Yönetim ve Ekonomi Araştırmaları Dergisi, 15(1), 85-112.

Ekim Akkan ve diğerleri (2011). Sosyal Dışlanmanın Roman Halleri. Edirne Roman Kültürü Araştırma Geliştirme Yardımlaşma ve Dayanışma Derneğisi, Boğaziçi Üniversitesi.

Fırat, M. ve İlhan, S. (2019). Çingenelerde Yoksulluk ve Sosyal Dışlanma: Malatya Örneği. Anemon Muş Alparslan Üniversitesi Sosyal Bilimler Dergisi, 7(3), 265-277.

Genç ve diğerleri (2015). Roman Çocuklarının Eğitim Süreci ve Akademik Başarılarında Sosyal Dışlanma Algısının Rolü. International Journal of Social Science, 33, 79-97.

Kahraman, F. (2015). Türkiye'de İç Göç ve Çocuk Yoksulluğu. Doktora Tezi, Süleyman Demirel Üniversitesi.

Karakaş, M. (2006). Yeni Yoksulluk Bağlamında Sosyal Kimlik ve Tüketimde Eşitsizlik. Gazi Üniversitesi İktisadi ve İdari Bilimler Fakültesi Dergisi, 7(2),1-16.

Kenrick, D. (2006). Çingeneler Ganj'dan Thames., TIRNAKÇI, Bahadır (Çev.), Homer Kitapevi ve Yayıncilık.

Kiren G., Ö. (2011). Türkiye'de Çocuk Yoksulluğu: Birleştirilmiş Yatay Kesit Verileriyle Tercih Modellerinin Uygulanmast. Doktora Tezi, Dokuz Eylül Üniversitesi. 
Koptekin, D. (2017). Biz Romanlar Siz Gacolar; Çingenel Roman Çocukların Kimlik İnşası.İletişim Yayınları.

Mayall, D. (2004). Gypsy Identities 1500-2000 From Egipcyans and Moon-men to the Ethnic Romany. Routledge Taylor \& Francis Group.

Merriam, S.B. (2015). Nitel Araştırma Desen ve Uygulama İçin Bir Rehber.TURAN, Selahattin (Çev.), Nobel Akademik Akademik Yayıncılık.

Nişancı, Ş. ve Işık, C. (2015). Etnisite Kavramının İdeolojik Serüveni. Kafkas Üniversitesi İIBF Dergisi, 6(9),195-224.

Özdemir, A. (2014). Romanlarda Çalışan Yoksulluğu: Sakarya Gazipaşa Mahallesi Örneği.Yüksek Lisans Tezi, Sakarya Üniversitesi Sosyal Bilimler Enstitüsü.

Özdemir, A. (2017). Roman Mahallelerinde Kentsel Dönüşümün Çalışma İlişkileri Üzerine Etkileri: Sakarya Gazipaşa Mahallesi Araştırması.Route Educational and Social Science Journal, v. 8,150-169.

Özateşler, G. (2013). Avrupa'da Roma/Çingeneler Üzerine Sosyal Politikalar. Dokuz Eylül Üniversitesi Edebiyat Fakültesi Dergisi, 2(3), 13-33.

Öztürk, A. El. (2008). Kentteki Çocuk Yoksulluğu: Keçiören Örneği. Yüksek Lisans Tezi.

Sipahi, E. B. (2006). Yoksulluğun Küreselleşmesi ve Kentsel Yoksulluk: Ekonomik ve Sosyal Boyutlarıyla Konya Örneğinde Yoksulluk. Selçuk Üniversitesi İ̈BF Sosyal ve Ekonomik Araştırmalar Dergisi, 6 (11), 172-189.

Şenses, F. (2014). Küreselleşmenin Öteki Yüzü Yoksulluk. İletişim Yayınları.

Teber, V. (2017). Sosyal Yardımların Çalışma Hayatındaki Olumsuz Etkileri: Tembellik. Pamukkale Üniversitesi, Tezsiz Yüksek Lisans Projesi.

Tokol, A. ve Alper, Y. (2017). Sosyal Politika. Dora Yayınc1lık.

Uçum, Özgür (2008). Kocaeli Çingenlerinde Evlenme Geleneği.Kocaeli Üniversitesi, Sosyal Bilimler Enstitüsü, Türk Dili ve Edebiyatı Anabilim Dalı, Yüksek Lisans Tezi.

Uğurlu, Örgen ve Duru, M. (2010). Kriz ve Kentsel Yerinden Edilme Sürecinde Çingeneler. II. Uluslararası Ekonomi Politik Konferansı: Kriz ve Kalkınma, Mimarlar Odası Ankara Şubesi Bülteni.

Uğurlu, Ö. (2013). Dönüşen Kentlerde Çingene Olmak: İzmit Örneği. Mülkiye Dergisi, 37(1), 71104.

Uzun, A.M. (2003). Yoksulluk Olgusu ve Dünya Bankası. Cumhuriyet Üniversitesi, Sosyal Bilimler Enstitüsü Dergisi,4(2), 155-173.

Ünver Erbaş, C. (2018). Araştırma Yöntemleri.Çağ Üniversitesi, Sosyal Bilimler Enstitüsü, İşletme Yönetimi Yüksek Lisans Prog., Ders Notları Sunumu, 2017-2018 Güz dönemi, 2017-2018.-40.

UNICEF, (2005). Çocukluk Tehdit Altında. Dünya Çocuklarının Durumu 2005, UNICEF Türkiye Temsilciliği.

Yusufoğlu, Ö. Ş. ve Kızmaz, Z. (2016). Parçalanmış Ailelerde Yoksulluk ve Sosyal Dışlanma: Elâzığ Örneği. Fırat Üniversitesi Sosyal Bilimler Enstitüsü, Social Sciences, 11(1), $27-$ 40. 